\title{
Interaction effects of magnesium and vitamins on Chlorella Vulgaris Beiijer cultures
}

\author{
Desouky, S. A., Usama, M. A., Ahmed, W. A. \\ Al-Azhar University, Faculty of Science, Botany and Microbiology Department, Assiut, 71524, Egypt.
}

Rec. 17 Sept, 2011 Accpt. 18 Oct, 2011

\begin{abstract}
This study show the effect of applied vitamins ascorbic acid (vitamin C) and thiamine (vitamin $\mathrm{B}_{1}$ ) on growth criteria, total photosynthetic pigments, total carbohydrate contents, total protein contents, free amino acids and proline of Chlorella vulgaris Beijer cultured for 7 days. The growth criteria (cell number and dry weight), total photosynthetic pigments, total carbohydrate contents, total protein contents, other free amino acids and proline of Chlorella vulgaris Beijer cultures were significantly increased when the algal cultures were subject to lower levels ( 1.5 and $3 \mathrm{ppm}$ ) of $\mathrm{MgCl}_{2}$ only. On the other side, under moderate and higher levels ( 45 and $6 \mathrm{ppm}$ ) of $\mathrm{MgCl}_{2}$ the cell number, dry weight, total photosynthetic pigments, total carbohydrate contents, total protein contents and other free amino acids of stressed Chlorella vulgaris Beijer cultures were significantly decreased. However, the soluble carbohydrate contents, soluble proteins and proline of Chlorella vulgaris Beijer cultures were significantly increased. Also, the growth criteria (cell count and dry weight), total photosynthetic pigments, total protein contents, other free amino acids and proline of Chlorella vulgaris Beijer cultures were significantly increased, when the algal cultures were subject to various levels $(1.5,34.5$ and $6 \mathrm{ppm})$ of $\mathrm{MgCl}_{2}$ and treated with $200 \mathrm{ppm}$ of either ascorbic acid or thiamine. However, the different carbohydrate fractions (soluble, insoluble and total carbohydrate), soluble proteins of Chlorella vulgaris Beijer cultures were significantly decreased. All these parameters content were compared with that those of the control cultures.
\end{abstract}

Key words: Chlorella vulgaris Beijer, ascorbic acid and thiamine, proline and other free amino acids

\section{Introduction}

It well known, that the macronutrient elements such as magnesium necessary for the growth and development of green plants and algae. Thus, the deficient or increased in the levels of these elements dangerous effect on growth and biological process. Magnesium is an essential ingredient of chlorophyll; the green plant pigment that gives leaves their color and enables plants to make food from sunlight. Magnesium is a metallic element represented by the symbol Mg. In this context, magnesium; it's a constituent of chlorophyll, is obviously an absolute requirement for pigmented algae of all groups and is also necessary for the formation of catalase. Magnesium is an essential cofactor or activator in many reactions, such nitrate reduction,

sulfate reduction, carboxylation reaction, decarboxylation reaction and phosphate transfers. Magnesium is also activates enzymes involved in nucleic acid synthesis, and bind together the subunits of ribosomes (Schute, 1964; Bowen, 1966 and Parisi and
Vallee, 1969). Magnesium markedly stimulated the hill reaction (Susor and Korgmann, 1966). The several means by which magnesium may act is summarized by Bidwell (1979): 1) it may link enzyme and substrate together, for example, in reactions involving phosphate transfer from ATP; 2) it may alter the equilibrium constant of a reaction by binding with product, as in certain kinase reactions; 3) it may act by complexing with an enzyme inhibitor; 4) it can form metalloprophyrins, such as chlorophyll; and 5) it can play a role in binding charged polysaccharide chains to one another, since it is a divalent cation.

(Finkle and Appleman, 1953 ${ }_{\mathrm{a}}$ ). found that magnesium deficiency interrupted cell multiplication. The Mg-deficient cells were up to 20-fold larger in volume than those grown in culture with sufficient $\mathrm{Mg}$. However, the increases in cell size paralleled by proportional increase in $\mathrm{N}$-content and dry mass. (Finkle and Appleman, 1953 b). demonstrated the cessation of chlorophyll synthesis in Mg-deficient medium. Chlorella

\footnotetext{
* Corresponding author:

Dr. Desouky, S. A.

\. Desouky_alazhar@yahoo.com 
cells deprived of magnesium become chlorotic, enlarged and extensively vacuolated (Retovsku and Klasterska, 1961). Magnesium-deficient algae can exhibit number of metabolic disturbances; nitrogen metabolism can be disturbed and there can be a temporary accumulation of carbohydrate material; (Pirson and Badour, 1961). an abnormally high quantity of labile phosphate may be produced.

Vitamins compounds are among, the organic nutritional factors required for continued growth of living organisms. In this respect, some authors working with various algal groups grown under normal conditions found that the addition of different vitamins was necessary for continued growth of these algae (Berland et al., 1978 and Swift, 1980). These vitamins are required in very low concentrations as cofactors by organisms which otherwise undergo purely autotrophic growth (Provasoli and Carlucci, 1974 and Desouky, 1995).

Aim of this investigation illustrated the main important role of some exogenously some organic additives (ascorbic acid and thiamine) counteract the adverse effects of $\mathrm{MgCl}_{2}$ on growth criteria, photosynthetic pigments, total carbohydrates contents, total protein contents, other free amino acid and proline contents of Chlorella vulgaris Beijer cultures.

\section{Materials and methods:}

\section{Tested alga:}

Chlorella vulgaris Beijer was collected from the River Nile and used as a test organism. Beijerinck's nutritive culture was used as a medium for enrichment and growth of the tested alga, (Stein, 1966).

\section{Treatments:}

Chlorella vulgaris Beijer cultures subjected to 00 (control) and $200 \mathrm{ppm}$ of ascorbic acid (vitamin $\mathrm{C}$ ) and thiamine (vitamin $\mathrm{B}_{1}$ ) in the absence or presence of different levels $(00,1.5,3,4.5$ and $6 \mathrm{ppm})$ of magnesium chloride for 7 days incubations.

\section{Analytical methods:}

\section{Determination of cell number:}

One drop of the algal suspension was pipette on the Haemocytometer $(0.1 \mathrm{~mm}$ depth), covered and left two minutes for algal setting. The mean counts of four replicates were taken into consideration and the results measured as cells $\mathrm{ml}^{-1}$ algal suspension.

\section{Determination of dry weight:}

A definite volume $(100 \mathrm{mls}$.) of alga suspension was filtered through weighed glass fiber filter. The cells after being precipitated on the filter were washed twice with distilled water and dried over night in an oven at $105{ }^{\circ} \mathrm{C}$. The data were expressed as $\mu \mathrm{g} 100 \mathrm{ml}^{-1}$ algal suspension.

\section{Determination of total photosynthetic pigments:}

The pigment fractions $\left(\mu \mathrm{g} \mathrm{m} 1^{-1}\right.$ algal suspension) chlorophyll a, chlorophyll $\mathrm{b}$ and carotenoids were calculated by using the equations mentioned by (Metzner et al., 1965).

Chlorophyll $\mathrm{a}=10.3 \mathrm{E}_{663}-0.918 \mathrm{E}_{664}$

Chlorophyll $b=19.7 \mathrm{E}_{664}-3.87 \mathrm{E}_{663}$

Carotenoids $=4.2 \mathrm{E}_{452}-(0.0264$ chloro. $\mathrm{a}+\mathbf{0 . 4 2 6}$ chloro. $\mathrm{b})$

\section{Determination of carbohydrate contents:}

Using the anthrone-sulphoric acid reagent according to the method by (Badour, 1959). The data are measured as $\mu \mathrm{g} \mathrm{mg}^{-1}$ dry weight.

\section{Determination of protein contents:}

Using folin phenol reagent according the method adapted by (Lowry et al., 1951). The data were measured as $\mu \mathrm{g} \mathrm{mg}^{-1}$ dry weight.

\section{Determination of proline:}

It was determined according to (Bates et al., 1973). methods. The results of proline contents are calculated ( $\mu \mathrm{g} \mathrm{mg}^{-1}$ dry weight).

\section{Determination of free amino acids:}

Free amino acids were extracted from fresh water algal suspension and calorimetrically determined using the method of (Moore and Stein, 1948). The free amino acid contents are calculated as $\mu \mathrm{g} \mathrm{mg}^{-}$ ${ }^{1}$ dry weight.

\section{Statistical Analysis:}

Four replicates were used in this study and the data were statistically analyzed to calculate the Least Significant Difference (L.S.D) according to (Snedecor and Cochray, 1980).

\section{Results}

The date present in this investigation showed the effect of exogenously natural organic additives and toxicity of $\mathrm{MgCl}_{2}$ on growth parameters (cell number and dry weight), total photosynthetic pigments, total carbohydrate, total protein, free amino acid 
and proline contents of Chlorella vulgaris Beijer cultures for 7 days incubation.

In this study, the growth criteria (cell count and dry weight) and total photosynthetic pigments of Chlorella vulgaris Beijer cultures were significantly increased up to the level $3 \mathrm{ppm}$ of $\mathrm{MgCl}_{2}$ only. However, under higher relatively level (6 ppm) of $\mathrm{MgCl}_{2}$, all these parameters were significantly decreased as compared with that of the control cultures.

Also, the maximum values of growth parameters (cell number and dry weight) and total photosynthetic pigments of Chlorella vulgaris cultures were $225 \%, 161 \%$ and $213 \%$ of that of the control cultures, when algal cultures subjected to $3 \mathrm{ppm} \mathrm{MgCl}_{2}$ only, respectively. Whereas, the minimum values of cell number, dry weight and total photosynthetic pigments of Chlorella vulgaris cultures were $93 \%, 96 \%$ and $77 \%$ of that of the control cultures when algal cultures subjected to $6 \mathrm{ppm} \mathrm{MgCl}_{2}$ only (Fig.1-a).

Thus, the maximum values of cell number, dry weight and total photosynthetic pigments were $359 \%, 186 \%$ and $289 \%$ of that of the control cultures when Chlorella vulgaris cultures subjected to $3 \mathrm{ppm} \mathrm{MgCl}_{2}$ and treated with $200 \mathrm{ppm}$ of ascorbic acid (Fig.1-b). The growth criteria (cell count and dry weight) and total photosynthetic pigments of Chlorella vulgaris cultures reached to $260 \%, 175 \%$ and $233 \%$ when compared with that those of the control cultures, when algal cultures subjected to 3 ppm $\mathrm{MgCl}_{2}$ and treated with $200 \mathrm{ppm}$ of thiamine (Fig. 1-c).

On the other side, the maximum value of soluble carbohydrates content amounted to $181 \%$ of that of the control cultures when algal cultures subjected to $4.5 \mathrm{ppm} \mathrm{MgCl}_{2}$. But, the maximum values of insoluble and total carbohydrates content reached to $151 \%$ and $154 \%$ of that of the control cultures, when algal cultures subjected to $3 \mathrm{ppm}$ $\mathrm{MgCl}_{2}$. On the other side, the minimum values of soluble, insoluble and total carbohydrates content amounted to $94 \%$, $85 \%$ and $87 \%$ of that of the control cultures when algal cultures subjected to $6 \mathrm{ppm}$ $\mathrm{MgCl}_{2}$, respectively (Table $1-\mathrm{a}$ ).

Addition $200 \mathrm{ppm}$ of either ascorbic acid or thiamine to different levels of $\mathrm{MgCl}_{2}$ changed the content of carbohydrate fractions (soluble, insoluble and total carbohydrates). In this context, the maximum values of soluble carbohydrates content amounted to $106 \%$, when algal subjected to1.5 ppm $\mathrm{MgCl}_{2}$ and treated with $200 \mathrm{ppm}$ ascorbic acid. Also, the maximum values of insoluble and total carbohydrate were $91 \%$ and $89 \%$ of that the control cultures, when the algal cultures subjected to $3 \mathrm{ppm} \mathrm{MgCl}_{2}$ and treated with $200 \mathrm{ppm}$ ascorbic acid, respectively (Table 1-b). On the other hand, the maximum value of soluble carbohydrates content reached to 101 $\%$ of that the control cultures, when the algal cultures treated with $200 \mathrm{ppm}$ thiamine and subjected to $1.5 \mathrm{ppm} \mathrm{MgCl}_{2}$. Also, the maximum values of insoluble and total carbohydrate were $86 \%$ and $83 \%$ of that the control cultures, when the algal cultures subjected to $3 \mathrm{ppm} \mathrm{MgCl}_{2}$ and treatment with $200 \mathrm{ppm}$ thiamine, respectively (Table $1-c)$.

The maximum values of soluble, insoluble and total protein contents of Chlorella vulgaris cultures amounted to $173 \%, 142 \%$ and $148 \%$ of that of the control cultures, when algal cultures subjected to 3 ppm $\mathrm{MgCl}_{2}$, respectively. However, the minimum values of soluble, insoluble and total protein contents amounted to $69 \%, 74 \%$ and $73 \%$ of that of the control cultures when algal cultures subjected to $6 \mathrm{ppm} \mathrm{MgCl}_{2}$, respectively (Table $2-a$ ).

In this respect, the maximum value of soluble protein contents amounted to $275 \%$ of that the control cultures when the algal cultures subjected to $4.5 \mathrm{ppm} \mathrm{MgCl}_{2}$ and treated with $200 \mathrm{ppm}$ ascorbic acid. Also, the maximum values of insoluble and total protein contents amounted to $211 \%$ and 211 $\%$ of that the control cultures when algal cultures subjected to $3 \mathrm{ppm} \mathrm{MgCl}_{2} 200 \mathrm{ppm}$ ascorbic acid. (Table 2-b). While, the maximum values of soluble Protein contents was $242 \%$ of that the control cultures, when the algal cultures subjected to $4.5 \mathrm{ppm}$ $\mathrm{MgCl}_{2}$ and treated with $200 \mathrm{ppm}$ thiamine. Also, the maximum values of insoluble and total protein contents amounted to the maximum values of insoluble and total protein contents amounted to $194 \%$ and $195 \%$ of that of the control cultures when algal cultures subjected to $3 \mathrm{ppm} \mathrm{MgCl}_{2}$ and treated with $200 \mathrm{ppm}$ thiamine, respectively (Table 2-c). 
Also, the maximum content of proline when algal cultures subjected to $6 \mathrm{ppm}$ $\mathrm{MgCl}_{2}$ was $574 \%$ of that of the control cultures (Fig. 2-a). In this context, the maximum values of proline contents reached to $145 \%$ and $254 \%$ of that of the control cultures when the algal cultures subjected to $6 \mathrm{ppm} \mathrm{MgCl}_{2}$ and treated with $200 \mathrm{ppm}$ of either ascorbic acid or thiamine, respectively. Also, the minimum values of proline contents were $176 \%$ and $103 \%$ of that the control cultures when the algal cultures subjected to $1.5 \mathrm{ppm} \mathrm{MgCl}_{2}$ and treated with $200 \mathrm{ppm}$ of either ascorbic acid and thiamine (Fig.2 b \& c).

Also, the maximum value of free amino acid contents amounted to $197 \%$ of that of the control cultures when algal cultures subjected to $3 \mathrm{ppm} \mathrm{MgCl}_{2}$ only, whereas the minimum value of free amino acids content was $64 \%$ when algal cultures subjected to 6 ppm $\mathrm{MgCl}_{2}$ only (Fig.2-a).

The maximum values of free amino acids content amounted to $344 \%$ and $329 \%$ of that of the control cultures, when algal cultures subjected to $3 \mathrm{ppm} \mathrm{MnCl}_{2}$ and treated with $200 \mathrm{ppm}$ of either ascorbic acid or thiamine, respectively. Also, the minimum values of free amino acids content amounted to $106 \%$ and $144 \%$ of that the control cultures, when the algal cultures subjected to $6 \mathrm{ppm} \mathrm{MnCl}_{2}$ and treated with $200 \mathrm{ppm}$ of either ascorbic acid or thiamine, respectively (Fig.2-b\& c).

In this context, the maximum values of free amino acids content reached to $447 \%$ and $415 \%$ of that of the control cultures, when algal cultures subjected to $3 \mathrm{ppm}$ $\mathrm{MgCl}_{2}$ and treated with $200 \mathrm{ppm}$ of either ascorbic acid or thiamine, respectively. Also, the minimum values of free amino acids content amounted to $106 \%$ and $144 \%$ of that the control cultures, when the algal cultures subjected to $6 \mathrm{ppm} \mathrm{MgCl}_{2}$ and treated with $200 \mathrm{ppm}$ of either ascorbic acid or thiamine, respectively (Fig.2 b\& c).

\section{Discussion}

This study elucidated effect of some natural organic additives such as ascorbic acid (vitamin $\mathrm{C}$ ) and thiamine (vitamin $\mathrm{B}_{1}$ ) and $\mathrm{Mg}^{2+}$ on the growth criteria, total photosynthetic pigments, total carbohydrates, total proteins, other free amino acids and proline of Chlorella vulgaris cultures for 7 days incubation.

The growth criteria (cell number and dry weight and photosynthetic pigments) of Chlorella vulgaris under successive levels of $\operatorname{MgCl} 2(1.5,3,4.5$ and $6 \mathrm{ppm})$ exhibited variable responses. Thus, the growth parameters significantly increased under lower levels (1.5 and $4.5 \mathrm{ppm})$ of $\mathrm{MgCl}_{2}$. But, under high relatively concentrations ( 6 ppm) of $\mathrm{Mg} \mathrm{Cl}_{2}$ the growth criteria and photosynthetic pigments were significantly decreased.

The results in this study showed the total carbohydrate contents of Chlorlla vulgaris cultures were significantly increased when the algal cultures subjected to lower levels (1.5 and $3 \mathrm{ppm}$ ) of $\mathrm{Mg}^{+2}$. While under higher level ( $6 \mathrm{ppm}$ ) of $\mathrm{MgCl}_{2}$ the carbohydrate contents were significantly decreased. However, the soluble carbohydrate contents were increased with the increased of $\mathrm{MgCl}_{2}$ in the medium cultures. Under higher concentration of $\mathrm{MgCl}_{2}$ the total carbohydrates were significantly decreased, when compared with that the control cultures. These results present in this study are in agreement with, (Fathi et al., 2005). reported that the higher doses of heavy metals severely attenuate chlorophyll synthesis coupled with severe drop in protein resulting in increased carbohydrates. In this respect, (Desouky, 2004). found that the total carbohydrate contents of Chlorella vulgaris cultures were significantly decreased when the algal cultures were subjected to various concentrations of $\mathrm{Cd} \mathrm{Cl}_{2}$.

On the other hand, the results in this study showed the protein contents of Chlorella vulgaris cultures were significantly increased, when the algal cultures subjected to lower levels (1.5 and 3 ppm) of $\mathrm{MgCl}_{2}$. Under higher level of (6 ppm) of $\mathrm{MgCl}_{2}$ the total protein contents were significantly decreased. However, under higher concentration (6 ppm) of $\mathrm{MgC} ; \mathrm{l}_{2}$, the soluble proteins were significantly increased while the total protein contents were decreased, when compared with that the control cultures. The results in this investigation in accordance with (Afkhar et al., 2010). recorded that the total protein contents of the green alga Chlorella vulgaris gradually decreased in a 
manner dependent on the metal concentration in the medium.

The results of this investigation show that the free amino acids of Chlorella vulgaris cultures were markedly increased when the algal cultures subjected to lower levels of $\mathrm{Mg}^{+2}$.

Generally, the accumulation of amino acids in response to metals concentrations may lead to the assumption that suppressed protein biosynthesis encouraged free amino acids accumulation, or may be due to some counteracting chelating mechanism against heavy metals toxicity (El-Sheekh et al., 2003; Osman et al., 2004; Fathi et al., 2005).

Also, the results in this study showed the proline contents of Chlorlla vulgaris cultures were significantly increased, when the algal cultures subjected to lower levels 1.5 and $3 \mathrm{ppm})$ of $\mathrm{MgCl}_{2}$. Under higher level (6 ppm) of $\mathrm{MgCl}_{2}$ the proline accumulation were significantly increased .

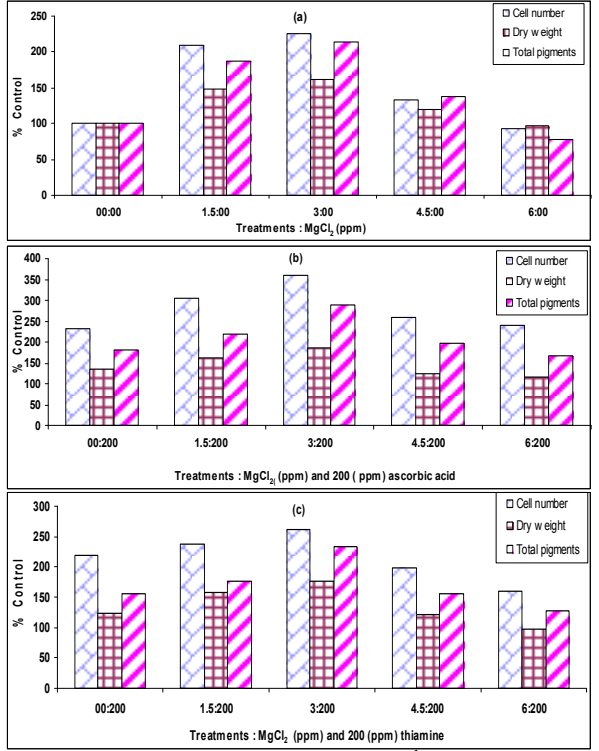

Figure (1): Cell number (cell $\mathrm{ml}^{-1}$ algal suspension), dry weight ( $\mu \mathrm{g} \mathrm{ml}^{-1}$ algal suspension) and total photosynthetic pigments ( $\mu \mathrm{g} \mathrm{ml}^{-1}$ algal suspension) of Chlorella vulgaris Beijer cultures subjected to various combinations of $\mathrm{MgCl}_{2}$ and $200 \mathrm{ppm}$ of either ascorbic acid (vitamin $\mathrm{C}$ ) or thiamin (vitamin $\mathrm{B}_{1}$ ) for 7 days.

\begin{tabular}{|c|c|c|c|c|c|c|}
\hline $\begin{array}{c}\text { Treatments } \\
\mathrm{MoCl}(\mathrm{nnm})\end{array}$ & \multirow[t]{2}{*}{$\begin{array}{l}\text { Water-soluble } \\
\text { Carbohydrates }\end{array}$} & \multirow[t]{2}{*}{$\begin{array}{c}\% \\
\text { Control }\end{array}$} & \multirow[t]{2}{*}{$\begin{array}{l}\text { Water-insoluble } \\
\text { Carbohydrates }\end{array}$} & \multirow[t]{2}{*}{$\begin{array}{c}\% \\
\text { Control }\end{array}$} & \multirow[t]{2}{*}{$\begin{array}{c}\text { Total } \\
\text { Carbohydrates }\end{array}$} & \multirow[t]{2}{*}{$\begin{array}{c}\% \\
\text { Control }\end{array}$} \\
\hline $\mathrm{MgCl}_{2}(\mathbf{p p m})$ & & & & & & \\
\hline \multicolumn{7}{|c|}{ (a) $\mathrm{MgCl}_{2}$} \\
\hline $00: 00$ & 35.00 & 100.00 & 166.00 & 100.00 & 201.00 & 100.00 \\
\hline $1.5: 00$ & $42.14 * *$ & 120.40 & $225.84 * *$ & 136.10 & $268.01 * *$ & 133.34 \\
\hline $3: 00$ & $58.47 * *$ & 167.10 & $251.00 * *$ & 151.20 & $309.47 * *$ & 154.00 \\
\hline 4.5:00 & $63.37 * *$ & 181.10 & $220.47 * *$ & 132.80 & $238.84 * *$ & 141.20 \\
\hline $6: 00$ & $32.02 * *$ & 94.60 & $142.05 * *$ & 85.60 & $175.17 * *$ & 87.10 \\
\hline L.S.D at $1 \%$ & 3.556 & & 10.232 & & 18.408 & \\
\hline L.S.D at $5 \%$ & 5.211 & & 15.122 & & $r r, 1 \cdot \varepsilon$ & \\
\hline \multicolumn{7}{|c|}{ (b) : Ascorbic acid ( vitamin C ) } \\
\hline \multicolumn{7}{|l|}{$\begin{array}{c}\mathrm{MgCl}_{2}(\mathrm{ppm}): \\
\text { Ascorbic acid (ppm) }\end{array}$} \\
\hline 200.00 & $55.58 * *$ & 158.80 & $21.4 .24 * *$ & 129.00 & $269.00 * *$ & 133.80 \\
\hline $1.5: 200$ & $37.11 * *$ & 106.00 & $136.80 * *$ & 82.40 & $173.91 * *$ & 86.50 \\
\hline $3: 200$ & $28.45 * *$ & 8130 & $151.31 * *$ & 91.20 & $176.76^{* * *}$ & 89.40 \\
\hline 4.5:200 & $24.31 * *$ & 69.50 & $140.54 * *$ & 84.70 & $164.85^{* *}$ & 82.00 \\
\hline $6: 200$ & $20.34 * *$ & 58.10 & $122.34 * *$ & 73.70 & $142.68 * *$ & 71.00 \\
\hline L.S.D at $1 \%$ & 1.177 & & 8.127 & & 7.012 & \\
\hline L.S.D at $5 \%$ & 2.101 & & 14.056 & & 10.234 & \\
\hline \multicolumn{7}{|c|}{ (c): Thiamine (vitamin $\left.\mathrm{B}_{1}\right)$} \\
\hline \multicolumn{7}{|l|}{$\begin{array}{l}\mathrm{MgCl}_{2}(\mathrm{ppm}): \\
\text { Thiamine (ppm) }\end{array}$} \\
\hline 200.00 & $58.51 * *$ & 167.17 & $195.00 * *$ & 117.50 & $253.75 * *$ & 126.24 \\
\hline $1.5: 200$ & $35.35 * *$ & 101.00 & $123.05 * *$ & 74.10 & $158.40 * *$ & 78.80 \\
\hline $3: 200$ & $24.47 * *$ & 69.91 & $144.13 * *$ & 86.80 & $168.60 * *$ & 83.90 \\
\hline 4.5:200 & $21.56 * *$ & 61.60 & $131.84 * *$ & 79.50 & $153.50 * *$ & 76.40 \\
\hline $6: 200$ & $18.60 * *$ & 53.10 & $116.60^{* *}$ & 70.24 & $135.20 * *$ & 67.30 \\
\hline L.S.D at $1 \%$ & 1.020 & & 4.021 & & 10.021 & \\
\hline L.S.D at $5 \%$ & 2.020 & & 8.014 & & 16.017 & \\
\hline
\end{tabular}

Table (1): Carbohydrate contents ( $\mu \mathrm{g} \mathrm{mg}^{-1}$ dry weight) of Chlorella vulgaris Beijer cultures subjected to various concentrations of $\mathrm{MgCl}_{2}$ and $200 \mathrm{ppm}$ of either ascorbic acid (vitamin C) or thiamine(vitamin $\mathrm{B}_{1}$ ) for 7 days.

*significantly.

** High significantly......... as compared with the control cultures. 


\begin{tabular}{|c|c|c|c|c|c|c|}
\hline Treatments & \multirow[b]{2}{*}{$\begin{array}{l}\text { Water-soluble } \\
\text { Proteins }\end{array}$} & \multirow[b]{2}{*}{$\begin{array}{c}\% \\
\text { Control }\end{array}$} & \multirow[b]{2}{*}{$\begin{array}{c}\text { Water-insoluble } \\
\text { Proteins }\end{array}$} & \multirow[b]{2}{*}{$\begin{array}{c}\% \\
\text { Control }\end{array}$} & \multirow[b]{2}{*}{ Total Proteins } & \multirow[b]{2}{*}{$\begin{array}{c}\% \\
\text { Control }\end{array}$} \\
\hline $\mathrm{MgCl}_{2}(\mathrm{ppm})$ & & & & & & \\
\hline \multicolumn{5}{|c|}{ (a) $\mathrm{Mg} \mathrm{Cl}_{2}$} & & \\
\hline $00: 00$ & 40.00 & 100.00 & 155.00 & 100.00 & 195.00 & 100.00 \\
\hline $1.5: 00$ & $55.22 * *$ & 138.10 & $195.24 * *$ & 126.00 & $250.46 * *$ & 125.40 \\
\hline $3: 00$ & $69.54 * *$ & 173.90 & $220.55^{* *}$ & 142.30 & $290.09 * *$ & 145.80 \\
\hline 4.5:00 & $67.35 * *$ & 168.40 & $164.23 * *$ & 106.00 & $231.58 * *$ & 118.80 \\
\hline 6:00 & $27.84 * *$ & 69.60 & $115.24 * *$ & 74.30 & $1 \leq \Gamma, \cdot \wedge * *$ & 73.40 \\
\hline L.S.D at $1 \%$ & 4.123 & & 5.123 & & 20.123 & \\
\hline L.S.D at $5 \%$ & 9.147 & & 8.012 & & 35.012 & \\
\hline \multicolumn{7}{|c|}{ (b): Ascorbic acid (vitamin C) } \\
\hline \multicolumn{7}{|l|}{$\begin{array}{c}\mathbf{M g C l}_{2}(\mathrm{ppm}): \\
\text { Ascorbic acid (ppm) }\end{array}$} \\
\hline $200: 00$ & $65.25 * *$ & 163.13 & $242.35 * *$ & 156.37 & $207.60 * *$ & 157.74 \\
\hline $1.5: 200$ & $77.32 * *$ & 193.30 & $288.35 * *$ & 186.00 & $365.67 * *$ & 187.50 \\
\hline $3: 200$ & $84.32 * *$ & 210.80 & $327.24 * *$ & 211.10 & $411.56^{* *}$ & 211.00 \\
\hline $4.5: 200$ & $110.25 * *$ & 275.60 & $254.00 * *$ & 163.90 & $364.25^{* *}$ & 186.80 \\
\hline 6:200 & $68.25 * *$ & 170.60 & $210.36 * *$ & 135.72 & $278.61 * *$ & 142.90 \\
\hline L.S.D at $1 \%$ & 12.456 & & 30.012 & & 20.012 & \\
\hline L.S.D at $5 \%$ & 20.123 & & 50.012 & & 42.012 & \\
\hline \multicolumn{7}{|c|}{ (c) : Thiamine (vitamin $\left.\mathrm{B}_{1}\right)$} \\
\hline \multicolumn{7}{|l|}{$\begin{array}{l}\mathrm{MgCl}_{2}(\mathrm{ppm}): \\
\text { Thiamine (ppm) }\end{array}$} \\
\hline $200: 00$ & $54.55^{*}$ & 136.38 & $222.54 * *$ & 143.57 & $276.00 * *$ & 141.50 \\
\hline $1.5: 200$ & $71.38 * *$ & 178.50 & $260.77 * *$ & 168.20 & $332.15 * *$ & 170.30 \\
\hline 3:200 & $79.51 * *$ & 198.80 & $301.26^{* *}$ & 194.40 & $380.77 * *$ & 195.30 \\
\hline $4.5: 200$ & $97.13^{* *}$ & 242.80 & $236.96 * *$ & 154.80 & $337.09 * *$ & 172.90 \\
\hline $6: 200$ & $50.20 * *$ & 125.50 & $194.38 * *$ & 125.40 & $244.58 * *$ & 125.40 \\
\hline L.S.D at $1 \%$ & 8.040 & & 24.0123 & & 25.012 & \\
\hline L.S.D at $5 \%$ & 15.012 & & 30.125 & & 33.125 & \\
\hline
\end{tabular}

Table (2): Proteins content ( $\mu \mathrm{g} \mathrm{mg}^{-1}$ dry weight) of Chlorella vulgaris Beijer cultures subjected to various concentrations of $\mathrm{MgCl}_{2}$ and $200 \mathrm{ppm}$ of either ascorbic acid (vitamin $\mathrm{C}$ ) or thiamine (vitamin

$\mathrm{B}_{1}$ ) for 7 days incubation.

* significantly.

** High significantly....

with the control cultures.

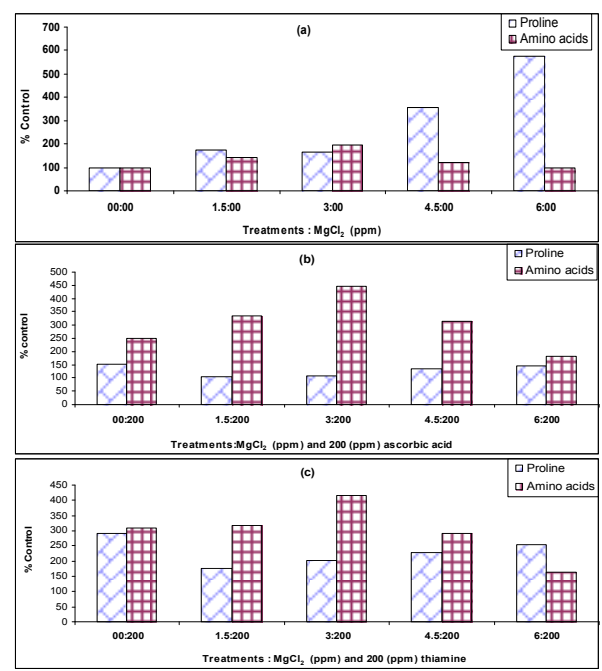

Figure (2): Proline contents and free amino acids ( $\mu \mathrm{g}$ $\mathrm{mg}^{-1}$ dry weight) of Chlorella vulgaris cultures subjected to various combinations of $\mathrm{MgCl}_{2}$ and 200 ppm of either ascorbic acid (vitamin $\mathrm{C}$ ) or thiamin (vitamin $\mathrm{B}_{1}$ ) for 7 days incubation.

\section{References}

Afkar, E., Abanna H. and Fathi, A.A. (2010). Toxicology response of green algae Chlorella vulgaris, to some heavy metals. Amer. J. Enviro. Sci. 230-237.

Alia, S.P. and Mohanty, P. (1991). Proline enhances primary photochemical activities in isolated thylakoid membranes of Brassica juncea by arresting photoinhibitory damage. Biochem. Biophys. Res. Commun. 181: 1238-1244.

Badour, S.S.A. (1959). Analytish-chemish untersuchung des kaliummangles bei Chlorella im vergleich mit anderen Mangelzustän den, Ph.Dissertation. Goettingen.

Bassi, R. and Sharma, S.S. (1993). Proline accumulation in wheat seedling exposed to zinc and copper. Phytochem. 33, 1339-1342. 
Bates, L.S., Waldren, R.P. and Teare, I.D. (1973). Rapid determination of free proline for water stress studies. Plant Soil 39: 205-207.

Berland, B.R., Bonin, D.J., Fiala, M. and Maestrini, S.Y. (1978). importance des vitamins en mer. Consommation et production par less algus et les bacteries. In: Actualites de Biochimie marine. Collaque G.A.B.I.M.C.N.R.S., Marseille (1976), Ed. Special du C.N.R.S., Paris.

Bidwell, R.G.S. (1979). Plant Physiology, 2nd (ed.), Macmillan, New York.

Bowen, H.J.M. (1966). Trace Elements in Biochemistry, Academic Press, London.

Bowen, H.J.M. (1966). Trace Elements in Biochemistry, Academic Press, London.

Desouky, S.A. (1995). :Effect of some organic additives on salinized Chlorella vulgaris. Ph.D.Thesis,Fac.Sci., Assiut Univ., Egypt pp : 1- 199

Desouky, S.A. (2004). Response of cadmium -stressed Chlorella vulgaris Beijer cultures to riboflavin $\left(B_{1}\right)$. The Sec. Int. Conf. for Develop. In the Arabic world, March, 23-25 .pp:37-48.

El-Sheekh, M.M., El-Naggar, A.H., Osman, M.E.H. and El-Mazaly, E. (2003). Effect of Cobalt on growth, pigments and the photos ynthetic electron transport in Monoraphidium minutum and Nitzchia perminuta.Braz. J. Plant Physiol., 15: 159-166.

Fathi, A.A., Zaki, F.T. and Ibraheim, H.A. (2005). Response of tolerant and wild type strains of Chlorella vulgaris to Copper with special references to Copper uptake system. Protistology, 4: 73-78.

Finkle, B.J. and Appleman, D. $\left(1953_{\mathrm{a}}\right)$. The Effect of magnesium concentration on growth of Chlorella, Plant Physiol., 28,664 .

Finkle, B.J. and Appleman, D. $\left(1953_{\mathrm{b}}\right)$. The Effect of magnesium concentration on chlorophyll and catalyses development in Chlorella, Plant Physiol., 28, 652.

Lowry, O.H., Rosebrough, N.J., Farr, A.L. and Randall, R.J. (1951). Protein measurement with the Folin phenol reagent. J. Biol. Chem. 193, 265-275.
Metzener, H., Rau, H. und Senger, H. (1965). Untersuchungen Zur Synchronisierbarkeit einzelener Pigment-Mangel Mutanten Von Chlorella. Planta 65: 186-194.

Moore, S. and Stein, W. (1948). Photometric ninhydrine method for use in the chromatography of amino acids. J. Biol. Chem., 17: 367-388.

Omar, H.H. (2002). Bioremoval of Zinc ions by Scenedesmus obliquus and Scenedesmus quadricauda and its effect on growth and metabolism. Int. Biodeteriorat. Biodegrad. 50: 95-100.

Osman, M.E.H., Stein, A.H., El-Naggar, M.M., El-Sheekh and El-Mazally, E. (2004). Differential effects of $\mathrm{Co}^{+2}$ and $\mathrm{Ni}^{+2}$ on protein metabolism in Scenedesmus obliquus and Nitzschia perminuta. Environ. Toxicol. Pharmacol., 16: 169-178.

Parisi, A.F. and Vallee, B.L. (1969). Zinc metalloenzymes characteristics and significance in biology and medicine, Amer. J. Clin. Nutr., 22, 1222.

Provasoli, L. and Carlucci, A.F. (1974). Vitamins and growth regulators. In: Stewart, W.D.P. (ed.), Algal Physiology and Biochemistry , Blackwell scientific publications, Oxford, pp: 741-787

Pirson, A. and Badour, S.S.A. (1961). Kennzeichung von Mineralsalzmangelzustanden bei Grunalgen mit analytischenchemischen Methodik. I. Kohlenhydratspiegl, organischen Stickstoff und Chlorophyll bei Kalimangel im Vergleich mit Magnesium-und Maganmangel, Flora, Jena, 150, 243.

Retovsku, R. and Klasterska, I. (1961) Study of the growth and development of Chlorella populations in the culture as a whole. $\mathrm{V}$. The influence of $\mathrm{Mg} \mathrm{SO}_{4}$ on autospore formation, Folia Micro., 6,115 .

Schute, K.H. (1964). The Biology of the Trace Elements: Their Role in Nutrition, International Monographs, And London.

Snedecor, G.A. and Cochran, W.G. (1980). Statistical Methods, 11th Ed., The Iowa State Univ.Press, Ames,Iowa, U.S.A, pp: 172-334. 
Stein, J.R. (1966). Growth and mating of Gonium pectoral (Volvolcales) in defined media. J. Phycol. 2: 23-28.

Susor, W. A. and Korgmann, D. W. (1966). Triphsphopyridene nucleotide photoreduction with cell-free preparations of Anabaena variabilis, Biochim, Biophys, Acta, 120, 67.
Swift, D.G. (1980). Vitamins and phytoplankton growth. In: The Physiological ecology of phytoplankton. Morris, I. (ed) Blackwell, Scientific Publications, Oxford, London, Edinburgh, Boston, 6: 329-368.

التأثيرات المتداخلة للماغنسيوم والفيتامينات علي مزارع طحلب " الكلوريلّا فولجاربيس

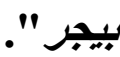

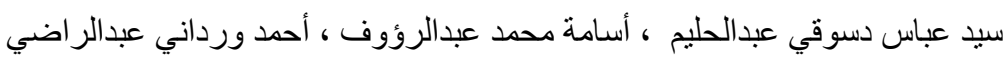

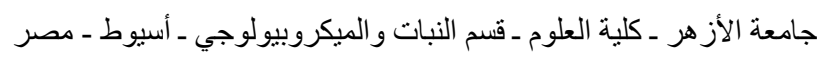

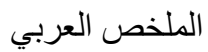
تزدداد معدلات النمو (عدد الخلايا والوزن الجاف) ، الأصباغ النباتية، محتوي المو اد الكربو هيدراتية الكلية، محتوي المو اد

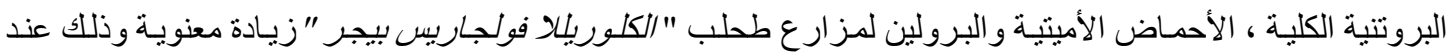
وضع الطحلب في النركيين (, إ و ؟ جزء من المليون) من كلوريد الماغسيوم. وتنتاقص معدلات النمو (عدد الخلايا

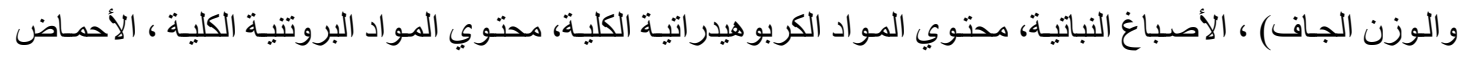

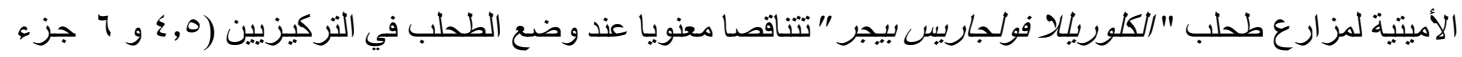
من المليون) من كلوريد الماغنسيوم.كما يلاحظ زيادة محتوي المو اد الكربو هيدر اتية ، والبروتينية و البرولين زيادة معنوية التية

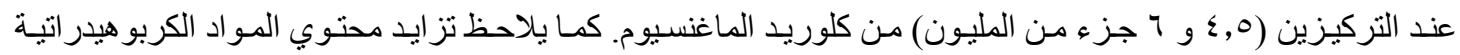
و البروتتية الذائبة و الرولين زيادة معنوية عند وصع الطحلب في المستويات العالية من كلوريد الماغنسيوم. كما يلاحظ

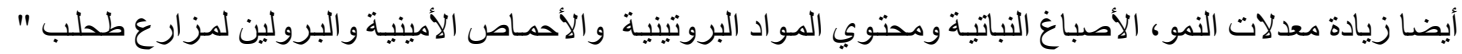

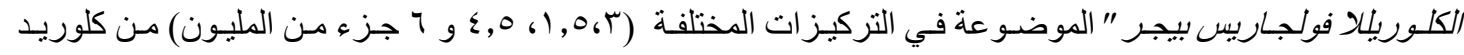

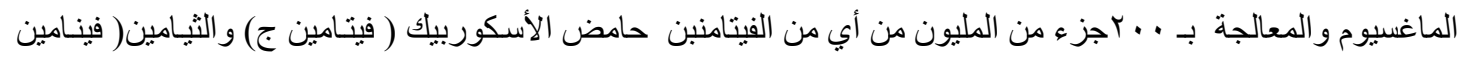

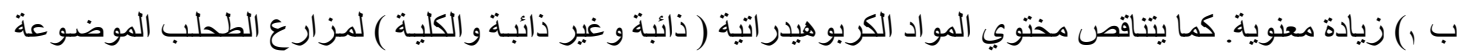

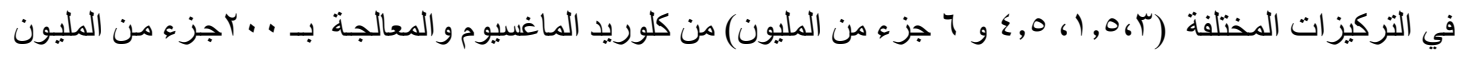

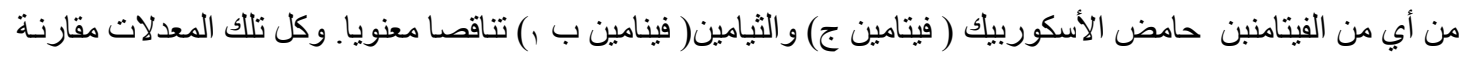
بمثيلاتها في المزرعة المقارنة ( . - كلوريد الماغنسيوم + +. فينامينات). 